\title{
Allelopathy of Cold Water Extracts from Origanum vulgare ssp. vulgare L.
}

\author{
Asya Pencheva Dragoeva, Vanya Petrova Koleva, Zheni Dimitrova Nanova*, \\ Mariya Zhivkova Kaschieva
}

Faculty of Natural Sciences, University of Shumen, Shumen, Bulgaria

Email: ${ }^{*}$ jenidim@gmail.com

Received 4 August 2014; revised 26 September 2014; accepted 8 October 2014

Copyright (C) 2014 by authors and Scientific Research Publishing Inc.

This work is licensed under the Creative Commons Attribution International License (CC BY).

http://creativecommons.org/licenses/by/4.0/

(c) (i) Open Access

\section{Abstract}

Secondary metabolites in medicinal plants could lead to discovery of new classes of herbicides. Recently aromatic plants have gained interest as a source of allelopathic secondary metabolites. Origanum vulgare ssp. vulgare $\mathrm{L}$. infusions in hot water are used in folk medicine and possess proved beneficial biological activity. Plant-to-plant variability of metabolites due to genetic heterogeneity is established in Lamiaceae family. From this point of view, studies on plants from different geographic regions might reveal important sources of variability. The objective of this study was to evaluate allelopathic activity of cold water extracts made from the aerial parts of $O$. vulgare ssp. vulgare growing wild in Northeast Bulgaria in laboratory conditions. The allelopathic effect was evaluated using root elongation test and Allium cepa-test. Oregano extracts $(17.5 \mathrm{~g} / \mathrm{l}, 52.5 \mathrm{~g} / \mathrm{l})$ significantly decreased root length of Triticum aestivum $\mathrm{L} .(\mathrm{P} \leq \mathbf{0 . 0 0 1})$. The root growth reduction could serve as a sign for presence of water soluble allelopathic secondary metabolites in the plant tested. Oregano (3.5 g/l) inhibited cell division in Allium root meristematic cells. The decline of the mitotic index indicates the occurrence of a cytotoxic effect. Oregano induced abnormalities in mitotic and interphase cells, so can be also considered as genotoxic. The observed macroscopic and microscopic effects of tested extracts indicated presence of water soluble allelochemicals in $O$. vulgare ssp. vulgare. This characteristic could be further studied as a possibility to be used in weed management programs.

\section{Keywords}

Origanum vulgare ssp. vulgare L., Allelopathy, Root Growth Inhibition, Allium cepa-Test

\footnotetext{
${ }^{*}$ Corresponding author.
}

How to cite this paper: Dragoeva, A.P., Koleva, V.P., Nanova, Z.D. and Kaschieva, M.Z. (2014) Allelopathy of Cold Water Extracts from Origanum vulgare ssp. vulgare L. Journal of Agricultural Chemistry and Environment, 3, 144-150. 


\section{Introduction}

Oregano (Lamiaceae) is a valuable aromatic plant found in natural conditions in Europe, Central Asia and North America [1]. One of the most commonly used subspecies is Origanum vulgare ssp. vulgare L. [2]. This plant occurs naturally in Bulgaria. Recently aromatic plants have gained interest as a source of allelopathic secondary metabolites. Allelopathy as a phenomenon where a plant chemically affects other plants has been known for centuries. The renewed interest in allelopathy to a great extent is due to the necessity to reduce synthetic chemical input into agriculture [3] [4]. According to [5] aromatic plants, such as oregano, could be used in agriculture for the suppression of some weeds. Allelochemicals could cause inhibition of seed germination and/or seedling growth [6]. A number of studies reported that germination was less sensitive than seedling growth [7]-[9]. According to [10] the inhibition of root growth and development by allelochemicals can be due to changes in DNA synthesis in cells of apical root meristem, alteration of the mitochondrial metabolism [11] or changes in cell mitotic indices [12]-[15].

Allelopathic activity of essential oils has been widely studied [16]-[18]. There are also data about water-soluble phytotoxic compounds in aromatic plants [5] [6]. Oregano hot water infusions are used in folk medicine and possess proved biological activity. According to data about different effect of extracts obtained at different temperature [19] [20], a matter of interest is evaluation of the biological activity of cold water extracts. Following secondary metabolites have been identified in water extract of $O$. vulgare ssp. vulgare: glicosides, coumarins, phenolic compounds and tannins, flavanonols, anthocyanins [21]. Some of these compounds have been reported as potent allelochemicals: phenolic compounds, namely rosemarinic acid, chlorogenic acid, caffeic acid [22][24]. It must be noticed that the bioactivities of crude extracts are often different to those seen for the individual components: crude plant extracts may contain different chemical constituents that interact in complex ways [25].

The objective of this study was to evaluate allelopathic activity of cold water extracts made from the aerial parts of Origanum vulgare ssp. vulgare growing wild in Northeast Bulgaria in laboratory conditions.

\section{Materials and Methods}

\subsection{Plant Materials}

Origanum vulgare ssp. vulgare growing wild in the vicinity of Shumen (Velino, Bulgaria) (latitude $43^{\circ} 18^{\prime} \mathrm{N}$; longitude $27^{\circ} 01$ 'E, altitude $227 \mathrm{~m}$ ) was used in this study. The aerial parts of oregano plants during the flowering stage were collected in June-July. The plant specimens were identified and authenticated by Nanova (Taxonomist), Faculty of Natural Sciences, Shumen University, Bulgaria. Collected plant materials were dried at a room temperature.

\subsection{Plant Water Extracts}

Aerial parts of oregano plants, cut about $20 \mathrm{~cm}$ from the top were used. The dried oregano tissue was placed in distilled water and left to stay for $24 \mathrm{~h}$ at room temperature. Oregano Cold Water Extracts (OCWE) were prepared at concentrations $3.5 \mathrm{~g} / \mathrm{l}, 17.5 \mathrm{~g} / \mathrm{l}$ (5× more concentrated) and $52.5 \mathrm{~g} / \mathrm{l}$ (15× more concentrated). The extracts were used after filtration.

\subsection{Root Elongation Test}

Twenty seeds of Triticum aestivum cv. GTW were placed on filter paper in each of three Petri dishes (11 cm in diameter). Five $\mathrm{ml}$ of OCWE (17.5 g/l and $52.5 \mathrm{~g} / \mathrm{l})$ or distilled water, as a control, was applied to the seeds. The dishes were sealed and incubated at $25^{\circ} \mathrm{C} \pm 1^{\circ} \mathrm{C}$ for $72 \mathrm{~h}$. The length of the roots of germinated seeds was measured. The percentage root growth inhibition in relation to the negative control for each extract was determined. Seeds that did not germinate were not included in the root elongation test. Three replications of each treatment were done.

\subsection{Allium cepa-Test}

Microscopic cytotoxic effects of OCWE were evaluated using Allium cepa-test [26]. Thirty seeds of A. cepa were placed on filter paper in each of three Petri dishes $(11 \mathrm{~cm}$ in diameter), containing $5 \mathrm{ml}$ of distilled water. 
The Petri dishes were sealed and incubated at $25^{\circ} \mathrm{C} \pm 1^{\circ} \mathrm{C}$ for $48 \mathrm{~h}$. Twenty germinated seeds with equal length of roots $(\sim 1 \mathrm{~cm})$ were removed and placed on filter paper in each of another three Petri dishes. Five ml of OCWE (3.5 g/l) were added to one of the dishes, and incubated at $25^{\circ} \mathrm{C} \pm 1{ }^{\circ} \mathrm{C}$ for $3 \mathrm{~h}$. Distilled water was used as a negative control and methyl methanesulfonate $(11 \mathrm{mg} / \mathrm{l}$, for $24 \mathrm{~h})$ was used as a positive control. After treatment, the roots were fixed in Clarke's fixative (95\% ethanol: acetic acid glacial, 3:1) for 90 min, hydrolysed in $3 \mathrm{~N} \mathrm{HCl}$ for $8 \mathrm{~min}$ and in $45 \%$ acetic acid $\left(\mathrm{CH}_{3} \mathrm{COOH}\right)$ for $30 \mathrm{~min}$ at room temperature and stained for 40 min in $2 \%$ acetoorseine. After staining, the terminal root tips $(1-2 \mathrm{~mm})$ were cut off and squashed in $45 \%$ $\mathrm{CH}_{3} \mathrm{COOH}$. The microscopic analysis included the mitotic index and scoring of aberrant cells. Each sample consisted of six root meristems. At least 1000 cells of each root meristem were analysed. The mitotic index was determined as a ratio between the number of cells in mitosis and the total number of analysed cells. The index of each phase of mitotic division was calculated as a ratio between the cell number in the respective period and the number of dividing cells.

\subsection{Statistical Analyses}

We processed the experimental data by Student's $t$-test. In germination and root inhibition test we choose as an experimental unit the root. The calculations were carried out on the assumption that roots used in each treatment made one sample, and each sample was tested against the control sample. In Allium cepa-test we choose as an experimental unit the cell, instead of the root. The calculations were carried out on the assumption that all the cells of the six root meristems made one sample, and each sample was tested against the negative control.

\section{Results and Discussion}

\subsection{Root Elongation Test}

In present study root growth inhibition of T. aestivum was used as index of general toxicity [27] [28]. Economou et al. [20] tested allelopathic influence of Greek oregano at concentrations in the $18.75-150 \mathrm{~g} / \mathrm{l}$ range. Keeping these data in view we tested OCWE at concentrations $17.5 \mathrm{~g} / \mathrm{l}$ and $52.5 \mathrm{~g} / \mathrm{l}$.

Data on growth inhibition effect of OCWE are presented in Table 1. As can be seen, both concentrations tested significantly inhibited root elongation of $T$. aestivum. This negative effect is dose dependent. The established root growth reduction could serve as a sign for presence of water soluble allelopathic secondary metabolites in the plant tested. This observation is in accordance to data that medicinal plants could possess allelopathic activity [6].

\subsection{Allium cepa-Test}

The macroscopic effect of plant extracts could be confirmed by microscopic studies providing definitive information regarding the extent of cytotoxic action [29]. We evaluated microscopic cytotoxic effects of OCWE using Allium cepa-test. The results of a preliminary experiment (data not shown) revealed a strong mitodepressive effect of OCWE at concentration of $17.5 \mathrm{~g} / \mathrm{l}$. It is not recommended to provide cytogenetic analysis if the mitotic index is very low [26]. So we provided Allium cepa-test using the concentration $3.5 \mathrm{~g} / \mathrm{l}$, normally used by population [30]. Treatment time of $3 \mathrm{~h}$ was used since this period corresponded to the earliest appearance of DNA damage [31] [32].

Table 1. Effect of OCWE on root elongation of Triticum aestivum L., germinated in the infusions over a period of $72 \mathrm{~h}$.

\begin{tabular}{lcccc}
\hline \multirow{2}{*}{ Sample } & \multicolumn{3}{c}{ Concentrations } & \multicolumn{2}{c}{$52.5 \mathrm{~g} / \mathrm{l}$} \\
\cline { 2 - 5 } & \multicolumn{3}{c}{$17.5 \mathrm{~g} / \mathrm{l}$} & \multicolumn{3}{c}{ Root length, $\mathrm{mm} \pm \mathrm{SD}$} & $\%$ compared to the control & Root length, $\mathrm{mm} \pm \mathrm{SD}$ & $\%$ compared to the control \\
\hline Control & $55.72 \pm 12.02$ & 100 & $55.72 \pm 12.02$ & 100 \\
OCWE & $33.29 \pm 7.35$ & $59.75^{* * *}$ & $16.33 \pm 4.26$ & $29.31^{* * *}$ \\
\hline
\end{tabular}

Data are expressed as means from three replications done $\pm \mathrm{SD}$ (standard deviation), ${ }^{* * *} \mathrm{P} \leq 0.001$, OCWE-Oregano Cold Water Extract, Control-distilled water. 
Table 2 summarizes the effect of OCWE on mitotic index and mitotic phase in the root meristematic cells of A. сера. Upon the treatment the mitotic index was decreased in comparison with the negative control. Allelochemicals can affect the plant growth by different manner: one of the principal mechanisms is the alteration of the mitotic index [33]. The decline of the mitotic index after treatment with OCWE indicates the occurrence of a cytotoxic effect [34]. The treatment also changed the mitotic phase distribution. The characteristic effect caused by OCWE was an increase of anaphase index and simultaneous decrease of telophase index. The interference in the cell cycle kinetics also is accepted as a sign of cytotoxic influence [35].

Table 3 shows the frequency and the types of abnormalities observed upon exposure of root tips of A. cepa to OCWE. The treatment with oregano significantly increased the percent of chromosome aberrations in comparison to negative control. Disturbed metaphases and anaphases (Figure 1(A) and Figure 1(B)) are the most frequently observed abnormality noted in the treated cells. Bridges and fragments in ana-telophase were the second (Figure 1(C) and Figure 1(E)). Laggard and vagrant chromosomes were also scored (Figure 1(D)). Disturbed metaphases and anaphases may be caused by inhibition of spindle formation [36] [37]. Laggard chromosomes also indicate spindle disturbances [26]. Fragments and bridges may be consequence of DNA breaks [38]. According to [34] chromosome bridges and breaks in mitotic cells are indicators of a clastogenic action. As can be
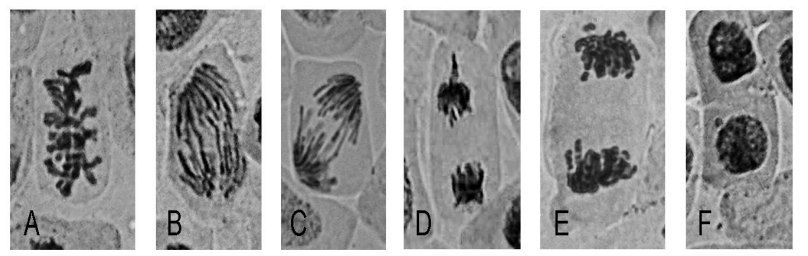

Figure 1. Aberrations induced by OCWE in Allium cepa root tips: (A) Abnormal metaphase; (B) Spindle abnormalities in anaphase; (C) Bridge; (D) Laggard chromosome in anaphase-telophase; (E) Anaphase-telophase with fragment; (F) Micronucleus in interphase cell.

Table 2. Effects of treatment with OCWE (3.5 g/l, for $3 \mathrm{~h}$ ) on mitotic index and phase indices in root tip meristematic cells of Allium cepa L.

\begin{tabular}{|c|c|c|c|c|c|c|c|}
\hline Sample & $\begin{array}{l}\text { Number } \\
\text { of cells } \\
\text { analysed }\end{array}$ & $\begin{array}{c}\text { Number } \\
\text { of dividing } \\
\text { cells }\end{array}$ & $\begin{array}{l}\mathrm{MI} \% \\
( \pm \mathrm{SD})\end{array}$ & $\begin{array}{c}\text { Prophase } \\
\text { PhI\% } \\
( \pm S D)\end{array}$ & $\begin{array}{c}\text { Metaphase } \\
\text { PhI\% } \\
( \pm \text { SD) }\end{array}$ & $\begin{array}{c}\text { Anaphase } \\
\text { PhI\% } \\
( \pm \text { SD) }\end{array}$ & $\begin{array}{c}\text { Telophase } \\
\text { PhI\% } \\
( \pm \text { SD) }\end{array}$ \\
\hline NC & 8895 & 510 & $\begin{array}{c}5.73 \\
( \pm 0.23)\end{array}$ & $\begin{array}{c}24.90 \\
( \pm 0.43)\end{array}$ & $\begin{array}{c}26.47 \\
( \pm 0.44)\end{array}$ & $\begin{array}{c}18.82 \\
( \pm 0.39)\end{array}$ & $\begin{array}{c}29.80 \\
( \pm 0.46)\end{array}$ \\
\hline OCWE & 10736 & 538 & $\begin{array}{c}5.01 \\
( \pm 0.22)^{*}\end{array}$ & $\begin{array}{c}25.46 \\
( \pm 0.44)\end{array}$ & $\begin{array}{c}26.39 \\
( \pm 0.44)\end{array}$ & $\begin{array}{c}23.98 \\
( \pm 0.42)^{*}\end{array}$ & $\begin{array}{c}24.16 \\
( \pm 0.43)^{*}\end{array}$ \\
\hline PC & 6982 & 251 & $\begin{array}{c}3.59 \\
( \pm 0.19)^{* * *}\end{array}$ & $\begin{array}{c}21.12 \\
( \pm 0.41)\end{array}$ & $\begin{array}{c}30.68 \\
( \pm 0.46)\end{array}$ & $\begin{array}{c}25.50 \\
( \pm 0.44)^{*}\end{array}$ & $\begin{array}{c}22.71 \\
( \pm 0.42)^{*}\end{array}$ \\
\hline
\end{tabular}

Sample: NC: negative control (distilled water); PC: positive control (methyl methanesulfonate, $11 \mathrm{mg} / \mathrm{l}$ ); OCWE: Oregano Cold Water Extracts. MI\%: Mitotic Index (\%); PhI\%: Phase Index (\%). Data are expressed as means $\pm \mathrm{SD}$ (standard deviation), ${ }^{*} \mathrm{P} \leq 0.05,{ }^{* * *} \mathrm{P} \leq$ 0.001 .

Table 3. Mitotic abnormalities and interphase cells with micronuclei in root tips of Allium cepa L. after treatment with OCWE (3.5 g/l, for $3 \mathrm{~h})$.

\begin{tabular}{|c|c|c|c|c|c|c|}
\hline \multirow[b]{2}{*}{ Sample } & \multicolumn{4}{|c|}{ Abnormalities, \% of mitotic cells } & \multirow{2}{*}{$\begin{array}{c}\text { Total abnormalities } \\
\text { in mitotic cells, } \\
\% \pm \text { SD }\end{array}$} & \multirow{2}{*}{$\begin{array}{l}\text { Micronuclei } \\
\text { in interphase } \\
\text { cells, \% } \% \text { SD }\end{array}$} \\
\hline & $\begin{array}{c}\text { Spindle } \\
\text { abnormalities } \\
\text { in metaphase }\end{array}$ & $\begin{array}{c}\text { Spindle } \\
\text { abnormalities } \\
\text { in ana-telophase }\end{array}$ & $\begin{array}{l}\text { Bridges and } \\
\text { fragments } \\
\text { in ana-telophase }\end{array}$ & $\begin{array}{l}\text { Laggard and } \\
\text { vagrant } \\
\text { chromosomes }\end{array}$ & & \\
\hline NC & - & 1.57 & 0.39 & 0.20 & $2.16 \pm 0.15$ & $0.12 \pm 0.04$ \\
\hline OCWE & 1.12 & 1.49 & 1.49 & 0.93 & $5.02 \pm 0.23^{*}$ & $0.27 \pm 0.05^{*}$ \\
\hline PC & 0.40 & - & 11.96 & 4.38 & $16.73 \pm 0.37^{* * *}$ & $0.47 \pm 0.07^{* * *}$ \\
\hline
\end{tabular}

Data are expressed as means \pm SD (standard deviation), ${ }^{*} \mathrm{P} \leq 0.05,{ }^{* * *} \mathrm{P} \leq 0.001$; Sample: NC: negative control (distilled water); PC: positive control (methyl methanesulfonate, $11 \mathrm{mg} / \mathrm{l}$ ); OCWE: Oregano Cold Water Extract. 
seen from Table 3, the most frequent aberrations were associated with spindle dysfunction (spindle abnormalities in metaphase and ana-telophase, laggard and vagrant chromosomes) rather than clastogenicity (bridges and fragments).

Additionally, we observed elevated percent of micronuclei in interphase cells in treated group as compared to those exposed to water only (Table 3). Micronuclei are extranuclear bodies of chromatin material (Figure 1(F)). These bodies result from damages, not or wrongly repaired, in the parental cells [34]. The frequency of cells with micronuclei is a good indicator of the cytogenetic effects of tested chemicals [38].

Data in Table 3 indicated that in addition to the cytotoxicity, OCWE can be also considered as genotoxic. These potentialities play important role in agroecosystems since the allelochemicals produced by plants can be utilized to protect the environment [27]. Application of allelopathic plant extracts can effectively control pests [39] [40] and identified natural products may lead to discovery of new herbicides [41].

The results of root elongation test and Allium cepa-test revealed allelopathic activity of $O$. vulgare ssp. vulgare growing wild in Northeast Bulgaria. Plant-to-plant variability of metabolites due to genetic heterogeneity is established in Lamiaceae family [42] [43]. Environmental factors and the stage of growth also influence Origanum composition [1]. From this point of view studies on plants from different geographic regions could reveal important sources of variability.

\section{Conclusion}

The observed macroscopic and microscopic effects of OCWE indicated presence of water soluble allelochemicals in O. vulgare ssp. vulgare growing wild in Northeast Bulgaria. This characteristic could be further studied as a possibility to be used in weed management programs.

\section{Acknowledgements}

This work was supported by the "Europian Social Fund 2007-2013, Human Resources Development Operarional Programe” under Grant [BG051PO001-3.3.06-0003] and the Bulgarian Ministry of Education and Science under Grant [RD-08-213/10.03.2014].

\section{References}

[1] Nurzyńska-Wierdak, R., Bogucka-Kocka, A., Sowa, I. and Szymczak, G. (2012) The Composition of Essential Oil from Three Ecotypes of Origanum vulgare L. ssp. vulgare Cultivated in Poland. Farmacia, 60, 571-577.

[2] Viturro, C.I., Molina, A.C., Villa, W.C. and Heit, C.I. (2010) Characterization of Origanum Species Grown in Quebrada de Humahuaca, Jujuy, Argentina, through the Study of the Essential Oils. Molecular Medicinal Chemistry, 21, 73-79.

[3] Duke, S.O. (2010) Allelopathy: Current Status of Research and Future of the Discipline: A Commentary. Allelopathy Journal, 25, 17-30.

[4] Bhadoria, P.B.S. (2011) Allelopathy: A Natural Way towards Weed Management. American Journal of Experimental Agriculture, 1, 7-20.

[5] Dhima, K.V., Vasilakoglou, I.B., Gatsis, Th.D., Panou-Philotheou, E. and Eleftherohorinos, I.G. (2009) Effects of Aromatic Plants Incorporated as Green Manure on Weed and Maize Development. Field Crops Research, 110, 235241. http://dx.doi.org/10.1016/j.fcr.2008.09.005

[6] Kruse, M., Strandberg, M. and Strandberg, B. (2000) Ecological Effects of Allelopathic Plants-A Review. NERITechnical Report No. 315, Silkeborg.

[7] Kakati, B. and Baruah, A. (2013) Allelopathic Effect of Aqueous Extract of Some Medicinal Plants on Seed Germination and Seedling Length of Mung Bean (Vigna radiata (L.) Wilczek.). Indian Journal of Plant Sciences, 2, 8-11.

[8] Verma, S.K., Kumar, S., Pandey, V., Verma, R.K. and Patra, D. (2012) Phytotoxic Effects of Sweet Basil (Ocimum basilicum L.) Extracts on Germination and Seedling Growth of Commercial Crop Plants. European Journal of Experimental Biology, 2, 2310-2316.

[9] Emeterio, S.L., Arroyo, A. and Canals, R.M. (2004) Allelopathic Potential of Lolium Rigidum Gaud. on the Early Growth of Three Associated Pasture Species. Grass and Forage Science, 59, 107-112. http://dx.doi.org/10.1111/j.1365-2494.2004.00410.x

[10] Gatti, A.B., Ferreira, A.G., Arduin, M. and Perez, S.C.G. de A. (2010) Allelopathic Effects of Aqueous Extracts of Artistolochia esperanzae O. Kuntze on Development of Sesamum indicum L. Seedlings. Acta Botanica Brasilica, 24, 
454-461. http://dx.doi.org/10.1590/S0102-33062010000200016

[11] Abrahim, D., Braguini, W.L., Kelmer-Bracht, A.M. and Ishii-Iwamoto, E.L. (2000) Effects of Four Monoterpenes on Germination, Primary Root Growth, and Mitochondrial Respiration of Maize. Journal of Chemical Ecology, 26, 611624. http://dx.doi.org/10.1023/A:1005467903297

[12] Dayan, F.E., Watson, S.B., Galindo, J.C.G., Hernandez, A., Dou, J., Mcchesney, J.D. and Duke, O. (1999) Phytotoxicity of Quassinoids: Physiological Responses and Structural Requirements. Pesticide Biochemistry and Physiology, 65, 15-24. http://dx.doi.org/10.1006/pest.1999.2432

[13] Romagni, J.G., Allen, S.N. and Dayan, F.E. (2000) Allelopathic Effects of Volatile Cineoles on Two Weedy Plant Species. Journal of Chemical Ecology, 26, 303-313. http://dx.doi.org/10.1023/A:1005414216848

[14] Pires, N.M., Souza, I.R.P., Prates, H.T., Faria, T.C.L., Pereira Filho, I.A. and Magalhaes, P.C. (2001) Efeito Do Extrato Aquoso De Leucena Sobre O Desenvolvimento, Indice Mitotico E Atividade Da Peroxidase Em Plantulas De Milho. Revista Brasileira de Fisiologia Vegetal, 13, 55-65. http://dx.doi.org/10.1590/S0103-31312001000100007

[15] Iganci, J.R.V., Bobrowski, V.L., Heiden, G., Stein, V.C. and Rocha, B.H.G. (2006) Efeito Do Extrato Aquoso De Diferentes Especies De Boldo Sobre A Germinacao E Indice Mitotico De Allium cepa L. Arquivos do Instituto Biolygico, 73, 79-82.

[16] Angelini, L.G., Carpanese, G., Cioni, P.L., Morelli, I., Macchia, M. and Flamini, G. (2003) Essential Oils from Mediterranean Lamiaceae as Weed Germination Inhibitors. Journal of Agricultural and Food Chemistry, 51, 6158-6164. http://dx.doi.org/10.1021/jf0210728

[17] Arminante, F., De Falco, E., De Feo, V., De Martino, L., Mancini, E. and Quaranta, E. (2006) Allelopathic Activity of Essential Oils from Mediterranean Labiatae. Acta Horticulturae (ISHS), 723, 347-356.

[18] De Almeida, L.F.R., Frei, F., Mancini, E., De Martino, L. and De Feo, V. (2010) Phytotoxic Activities of Mediterranean Essential Oils. Molecules, 15, 4309-4323.

[19] Ahn, J.K. and Chung, I.M. (2000) Allelopathic Potential of Rice Halls on Germination and Seedling Growth of Barnyardgrass. Agronomy Journal, 92, 1162-1167. http://dx.doi.org/10.2134/agronj2000.9261162x

[20] Economou, G., Travlos, I.S., Folinas, A. and Karamanos, A.J. (2007) Greek Oregano (Origanum vulgare ssp. hirtum) as Allelopathic Plant. Journal of Food, Agriculture and Environment, 5, 348-351.

[21] Bharti, V. and Vasudeva, N. (2013) Oreganum vulgare Linn. Leaf: An Extensive Pharmacognostical and Phytochemical Quality Assessment. Advanced Pharmaceutical Bulletin, 3, 277-281.

[22] Li, Z.-H., Wang, Q., Ruan, X., Pan, C.-D. and Jiang, D.-A. (2010) Phenolics and Plant Allelopathy. Molecules, 15, 8932-8952.

[23] Scognamiglio, M., Esposito, A., D’Abrosca, B., Pacifico, S., Fiumano, V., Tsafantakis, N., Monaco, P. and Fiorentino, A. (2012) Isolation, Distribution and Allelopathic Effect of Caffeic Acid Derivatives from Bellis perennis L. Biochemical Systematics and Ecology, 43, 108-113. http://dx.doi.org/10.1016/j.bse.2012.02.025

[24] Tahat, M.M. and Sijam, K. (2012) Arbuscular Mycorrhizal Fungi and Plant Root Exudates Bio-Communications in the Rhizosphere. African Journal of Microbiology Research, 6, 7295-7301.

[25] Cock, I.E. (2011) Problems of Reproducibility and Efficacy of Bioassays Using Crude Extracts, with Reference to Aloe vera. Pharmacognosy Communications, 1, 52-62. http://dx.doi.org/10.5530/pc.2011.1.3

[26] Rank, J. (2003) The Method of Allium Anaphase-Telophase Chromosome Aberration Assay. Ekologija Vilnius, 1, 3842.

[27] Sousa, S.M., Silva, P.S., Campos, J.M.S. and Viccini, L.F. (2009) Cytotoxic and Genotoxic Effects of Two Medicinal Species of Verbenaceae. Caryologia, 62, 326-333.

[28] Oyeyemi, I.T. and Bakare, A.A. (2013) Genotoxic and Anti-Genotoxic Effect of Aqueous Extracts of Spondias mombin L., Nymphea lotus L. and Luffa cylindrica L. on Allium cepa Root Tip Cells. Caryologia, 66, 360-367. http://dx.doi.org/10.1080/00087114.2013.857829

[29] Bhattacharya, S. and Haldar, P.K. (2010) Evaluation of in Vitro Cytotoxic Effect of Trichosanthes dioica Root. Pharmacognosy Research, 2, 355-358. http://dx.doi.org/10.4103/0974-8490.75454

[30] Nikolova, M. and Manolov, P. (2002) Reference Guide for Herbs. “P. Beron”, Sofia.

[31] Williams, G.O. and Omoh, L.E. (1996) Mitotic Effects of the Aqueous Leaf Extract of Cymbopogon citratus in Allium cepa Root Tips. Cytobios, 87, 161-168.

[32] Miyamae, Y., Zaizen, K., Ohara, K., Mine, Y. and Sasaki, Y.F. (1997) Detection of DNA Lesions Induced by Chemical Mutagens by the Single Cell Gel Electrophoresis (Comet) Assay. I. Relationship between the Onset of DNA Damage and the Characteristics of Mutagens. Mutation Research, 415, 229-235. http://dx.doi.org/10.1016/S1383-5718(97)00192-7

[33] Mohamed, F.I. and El-Ashry, Z.M. (2012) Cytogenetic Effect of Allelochemicals Brassica nigra L. Extracts on Pisum 
sativum L. World Applied Sciences Journal, 20, 344-353.

[34] Leme, D.M. and Marin-Morales, M.A. (2009) Allium cepa Test in Environmental Monitoring: A Review on Its Application. Mutation Research, 682, 71-81. http://dx.doi.org/10.1016/j.mrrev.2009.06.002 PMid:19577002

[35] Amin, W. (2002) Cytotoxicity Testing of Sewage Water Treatment Using Allium cepa Chromosome Aberrations Assay. Pakistan Journal of Biological Sciences, 5, 184-188. http://dx.doi.org/10.3923/pjbs.2002.184.188

[36] Sousa, S.M. and Viccini, L.F. (2011) Cytotoxic and Genotoxic Activity of Achillea millefolium Aqueous Extracts. Revista Brasiliera de Farmacognosia, 21, 98-104. http://dx.doi.org/10.1590/S0102-695X2011005000022

[37] Liman, R., Gökçe, U.G., Akyıl, D., Eren, Y. and Konuk, M. (2012) Evaluation of Genotoxic and Mutagenic Effects of Aqueous Extract from Aerial Parts of Linaria genistifolia subsp. Genistifolia. Revista Brasiliera de Farmacognosia, 22, 541-548.

[38] Maluszynska, J. and Juchimiuk, J. (2005) Plant Genotoxicity: A Molecular Cytogenetic Approach in Plant Bioassays. Arhiv za Higijenu Rada i Toksikologiju, 56, 177-184.

[39] Farooq, M., Jabran, K., Cheema, Z.A., Wahid, A. and Siddique, K.H. (2011) The Role of Allelopathy in Agricultural Pest Management. Pest Management Science, 67, 493-506. http://dx.doi.org/10.1002/ps.2091 PMid:21254327

[40] Koul, O., Walia, S. and Dhaliwal, G.S. (2008) Essential Oils as Green Pesticides: Potential and Constraints. Biopesticides International, 4, 63-84.

[41] Fujii, Y., Parvez, S.S., Parvez, M.M., Ohmae, Y. and Iida, O. (2003) Screening of 239 Medicinal Plant Species for Allelopathic Activity Using the Sandwich Method. Weed Biology and Management, 3, 233-241. http://dx.doi.org/10.1046/j.1444-6162.2003.00111.x

[42] Shetty, K. (2001) Biosynthesis and Medical Applications of Rosmarinic Acid. Journal of Herbs, Spices \& Medicinal Plants, 8, 161-181. http://dx.doi.org/10.1300/J044v08n02 05

[43] W'glarz, Z., Osidska, E., Geszprych, A. and Przybyb, J. (2006) Intraspecific Variability of Wild Marjoram (Origanum vulgare L.) Naturally Occurring in Poland. Revista Brasiliera de Plantas Medicinais, Botucatu, 8, 23-26. 
Scientific Research Publishing (SCIRP) is one of the largest Open Access journal publishers. It is currently publishing more than 200 open access, online, peer-reviewed journals covering a wide range of academic disciplines. SCIRP serves the worldwide academic communities and contributes to the progress and application of science with its publication.

Other selected journals from SCIRP are listed as below. Submit your manuscript to us via either submit@scirp.org or Online Submission Portal.
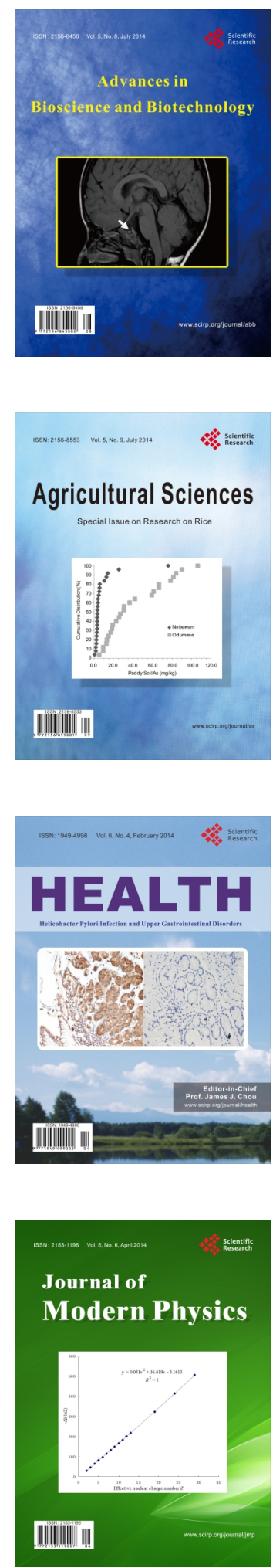
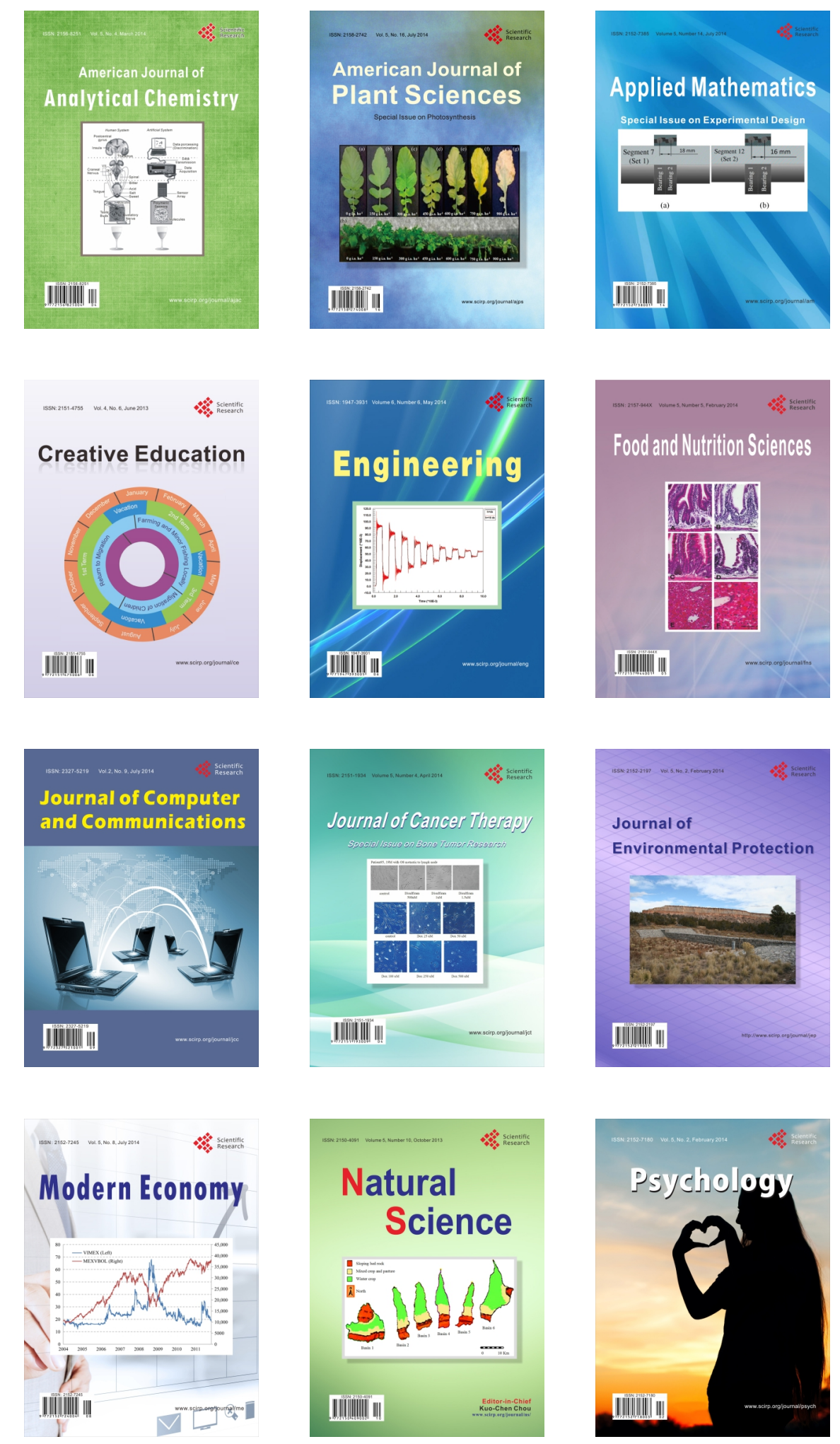